\title{
AKTIVITAS OLIGOSAKARIDA ALGINAT SEBAGAI ANTIOKSIDAN DAN INHIBITOR ALFA GLUKOSIDASE
}

\section{The Activity of Alginate Oligosaccharides as Antioxidant and Alpha Glucosidase Inhibitor}

\author{
Syahira Addina', Subaryono ${ }^{2}$, dan Sukarno ${ }^{1 *}$ \\ ${ }^{1}$ Program Studi IImu Pangan, Sekolah Pascasarjana, Institut Pertanian Bogor, \\ Kampus IPB Darmaga, Bogor, Jawa Barat, Indonesia \\ ${ }^{2}$ Balai Besar Riset Pengolahan Produk dan Bioteknologi Kelautan dan Perikanan, \\ JI. KS Tubun, Petamburan VI, Slipi, Jakarta, Indonesia \\ *Korespondensi Penulis: dsukarno@apps.ipb.ac.id
}

Diterima: 2 Januari 2020; Direvisi: 26 Maret 2020; Disetujui: 3 Juni 2020

\begin{abstract}
ABSTRAK
Oligosakarida alginat (OSA) adalah produk hasil depolimerisasi polimer alginat yang biasanya terdiri dari 2-25 monomer. Produksi OSA dapat dilakukan melalui proses enzimatis, fisik maupun kimiawi. Tujuan penelitian ini adalah mengetahui karakteristik dan bioaktivitas OSA sebagai antioksidan dan inhibitor $\alpha$-glukosidase. Proses produksi OSA dilakukan secara enzimatis dengan 3 cara penambahan alginat liase yaitu ditambahkan satu kali di awal reaksi (E1), ditambahkan 4 kali dengan interval 2 jam (E2) dan 2 kali interval 4 jam (E3) dengan total volume sama, yaitu $0,15 \mathrm{~mL}$ dan aktivitas enzim (1 unit/mL). Total waktu inkubasi adalah 8 jam. Karakterisasi OSA yang dilakukan adalah perhitungan rendemen, analisis profil TLC dan FTIR serta kadar gula pereduksi. Metode DPPH (1,1-diphenyl-2-picrylhydrazyl) digunakan untuk menguji aktivitas antioksidan OSA, sedangkan pengamatan terhadap aktivitas inhibitor $\alpha$-glukosidase dilakukan dengan melihat aktivitas $\alpha$-glukosidase dalam mengubah substrat yang diberikan. Hasil penelitian menunjukkan bahwa rendemen OSA dan kadar gula pereduksi tidak berbeda nyata antar perlakuan dengan rendemen OSA berkisar antara $77,29 \pm 1,97 \%$ hingga $85,46 \pm 9,15 \%$ dan kadar gula pereduksi OSA berkisar antara $290,32 \pm 20,42 \mu \mathrm{g} / \mathrm{mL}$ hingga $312,76 \pm 4,74 \mu \mathrm{g} / \mathrm{mL}$. Aktivitas antioksidan tertinggi diperlihatkan oleh OSA E1 dengan penghambatan terhadap DPPH sebagai radikal bebas sebesar $41,22 \pm 2,03 \%$ pada konsentrasi $1,2 \mathrm{mg} / \mathrm{mL}$. Aktivitas inhibitor $\alpha$-glukosidase OSA E1 lebih kecil dibandingkan dengan alginat dengan nilai $\mathrm{IC}_{50}$ masing-masing sebesar $11,23 \pm 4,17 \mathrm{ppm}$ dan $5,27 \pm 0,29 \mathrm{ppm}$. Proses depolimerisasi alginat meningkatkan aktivitas alginat sebagai antioksidan namun tidak meningkatkan aktivitasnya sebagai inhibitor $\alpha$-glukosidase.
\end{abstract}

KATA KUNCI : alginat, alginat liase, oligosakarida alginat, antioksidan, inhibitor $\alpha$-glukosidase

\section{ABSTRACT}

Alginate oligosaccharides (AOS) is depolymerization of alginate polymer product that consist of 2-25 monomers. Alginate oligosaccharides can be produced by enzymatic, physical and chemical processes. This research was conducted to find out the characteristics and bioactivity of AOS as an antioxidant and $\alpha$-glucosidase inhibitor. AOS was produced by enzymatic process with 3 procedures of the addition of the alginate lyase that was added once at the beginning reaction (E1), 4 times every 2 hours (E2) and 2 times every 4 hours (E3) with the same addition of enzyme volume $(0.15 \mathrm{~mL})$ and enzyme activity (1 unit/mL). Total incubation times was 8 hours. Alginate oligosaccharides was then characterized their yield, TLC, FTIR profiles and reducing sugar content. DPPH (1,1-diphenyl-2-picrylhydrazyl) method was used to determine antioxidant activity of AOS while observation of $\alpha$-glucosidase activity in changing the substrate was used to determine inhibitor $\alpha$-glucosidase activity of AOS. The results showed that yields and reducing sugar level of AOS were not significantly different between treatments. The AOS yields ranged from $77.29 \pm 1.97 \%$ to $85.46 \pm 9.15 \%$ and the reducing sugar levels ranged from $290.32 \pm 20.42 \mu \mathrm{g} / \mathrm{mL}$ to $312.76 \pm 4.74 \mu \mathrm{g} / \mathrm{mL}$. The highest antioxidant activity was shown by AOS E1 with free radical (DPPH) inhibition of $41.22 \pm 2.03 \%$. AOS E1 $\alpha$-glucosidase inhibitor activity was lower than that of alginate, with the $1 C_{50}$ values of $5.27 \pm 0.29 \mathrm{ppm}$ for alginate and $11.23 \pm 4.17 \mathrm{ppm}$ for AOS. Depolymerization process of alginates increased antioxidant activity but did not enhance its activity as $\alpha$-glucosidase inhibitor.

KEYWORDS: alginate, alginate lyase, alginate oligosaccharides, antioxidant, $\alpha$-glukosidase inhibitor 


\section{PENDAHULUAN}

Alfa glukosidase merupakan enzim yang berperan pada proses hidrolisis karbohidrat makanan menjadi glukosa sehingga dapat diserap ke dalam pembuluh darah. Enzim ini terikat pada membran epitel usus halus yang berfungsi untuk memfasilitasi penyerapan glukosa ke dalam darah (Kumar, Narwak, Kumar, \& Prakash, 2010). Enzim ini secara tidak langsung berperan dalam peningkatan glukosa di dalam darah, termasuk pada penderita diabetes. Penghambatan aktivitas $\alpha$-glukosidase akan menyebabkan proses pencernaan karbohidrat terhambat, sehingga menurunkan tingkat penyerapan glukosa ke dalam darah. Penghambatan aktivitas $\alpha$-glukosidase adalah salah satu cara untuk mencegah terjadinya peningkatan glukosa darah secara berlebih pada penderita diabetes.

Diabetes adalah penyakit kronis yang ditandai dengan meningkatnya kadar glukosa darah secara berlebih. Tingginya kadar glukosa darah pada penderita diabetes dapat menstimulasi terbentuknya radikal bebas di dalam tubuh, sehingga menyebabkan ketidakseimbangan ROS (Reactive Oxygen Species/ Spesies Oksigen Reaktif dan antioksidan yang diproduksi secara alami di dalam tubuh. Hal ini dapat menyebabkan kondisi stress oksidatif dalam tubuh yang dapat mengganggu sistem biologis. Keadaan stress oksidatif merupakan mediator terjadinya resisten insulin dan intoleransi glukosa yang akan memperparah diabetes (Tiwari, Pandey, Abidi, \& Rizvi, 2013). Oleh karena itu mengkonsumsi senyawa yang memiliki aktivitas antioksidan merupakan salah satu terapi yang dapat dilakukan untuk mencegah terjadinya stress oksidatif pada penderita diabetes.

Alginat merupakan polisakarida yang terbentuk di dinding sel alga coklat dan berperan penting dalam mempertahankan struktur jaringan alga. Alginat yang telah mengalami proses depolimerisasi disebut sebagai oligosakarida alginat (OSA). Subaryono, Peranginangin, Suhartono, dan Zakaria (2017) menyatakan bahwa OSA memiliki bioaktivitas yang lebih baik jika dibandingkan dengan polimer alginat itu sendiri. OSA telah terbukti memiliki kemampuan sebagai antioksidan (Falkeborg et al., 2014), antikanker (Iwamoto et al., 2005), antikoagulan (Zhou et al., 2007) dan antiinflamasi (Zhou et al., 2015). Penelitian yang dilakukan Hao et al. (2015) membuktikan bahwa OSA dapat meningkatkan sekresi insulin sehingga kadar glukosa dalam darah tikus dapat menurun. Terdapat beberapa mekanisme penurunan kadar glukosa dalam darah seperti melalui peningkatan sekresi insulin, peningkatan sensitivitas insulin, penghambatan penyerapan glukosa ke dalam darah dan penghambatan kerja enzim DPP IV
(Dipeptidil-peptidase IV) (PERKENI, 2011). Penelitian tentang OSA yang memiliki aktivitas sebagai antidiabetes khususnya pada mekanisme penghambatan penyerapan glukosa dalam darah belum banyak dilakukan sehingga penelitian ini akan mempelajari apakah OSA dapat menghambat kerja $\alpha$-glukosidase dan apakah aktivitasnya sebagai antioksidan dan inhibitor $\alpha$-glukosidase OSA lebih baik jika dibandingkan dengan polimer alginat itu sendiri.

Oligosakarida Alginat dapat diproduksi dari depolimerisasi alginat secara enzimatis (Subaryono, Peranginangin, \& Suhartono, 2013). Cara ini akan menghasilkan OSA yang lebih teratur strukturnya karena kerja alginat liase yang spesifik terhadap substrat polimanuronat dan poliguluronat. Kerja alginat liase pada reaksi enzimatis sangat dipengaruhi oleh $\mathrm{pH}$, suhu dan jumlah substrat (Kim, Lee, \& Lee, 2011). Kecepatan laju reaksi enzim akan meningkat dengan meningkatnya konsentrasi substrat namun pada batas konsentrasi substrat tertentu, tidak akan terjadi kenaikan kecepatan laju reaksi karena adanya sistem regulasi kerja enzim. Selama reaksi enzimatis, akan terjadi perubahan kondisi seperti perubahan jumlah substrat dan jumlah produk yang dihasilkan. Jumlah substrat pada awal reaksi lebih pekat jika dibandingkan dengan akhir reaksi serta jumlah produk akan lebih banyak di akhir reaksi dari pada di awal reaksi. Peningkatan jumlah produk yang dihasilkan ini dapat menyebabkan kerja enzim menurun karena efek allosterik enzim. Enzim yang bersifat alosterik akan mengikat modulator enzim (biasanya end product) pada sisi alosteriknya yang akan menyebabkan aktivitas enzim akan semakin menurun dengan bertambahnya jumlah produk selama reaksi enzimatis. Penambahan enzim secara bertahap pada penelitian ini diharapkan dapat meningkatkan kembali kerja enzim apabila terjadi penurunan kerja enzim selama proses depolimerisasi alginat. Oligosakarida alginat yang dihasilkan dari perlakuan ini dipelajari karakteristik dan bioaktivitasnya sebagai antioksidan dan inhibitor $\alpha$-glukosidase.

\section{BAHAN DAN METODE}

\section{Bahan}

Bahan utama yang digunakan adalah rumput laut coklat Sargassum crassifolium yang berasal dari Perairan Tepus, Gunung Kidul, Yogyakarta. Bahan ekstraksi alginat meliputi $\mathrm{HCl}, \mathrm{Na}_{2} \mathrm{CO}_{3}, \mathrm{NaOH}$ serta isopropil alkohol; semuanya dengan mutu teknis. Bahan yang digunakan untuk pembuatan OSA adalah alginat liase (Sigma-Aldrich), buffer fosfat (LabChem), aquades dan etanol $98 \%$ (Merck). Bahan lainnya yang digunakan untuk analisis adalah $\alpha$-glukosidase 
(Sigma-Aldrich), maltose (Merck), acarbose (Merck), 1-butanol (Merck), asam format (Merck), $\mathrm{H}_{2} \mathrm{SO}_{4}$ (Merck), lempeng TLC silica G 60 (Merck) dan $\mathrm{KBr}$ (Merck).

\section{Metode}

Penelitian ini dilakukan dalam empat tahap kegiatan yaitu tahap ekstraksi alginat, pembuatan oligosakarida alginat (OSA), pengujian aktivitas antioksidan OSA dan pengujian aktivitas inhibitor $\alpha$-glukosidase OSA.

\section{Ekstraksi alginat}

Ekstraksi alginat dilakukan melalui jalur asam alginat yang mengacu pada metode Husni, Subaryono, Pranoto, Tazwir, dan Ustadi (2012) tanpa adanya proses pemutihan menggunakan $\mathrm{NaOCl}$. Rumput laut kering direndam dalam $\mathrm{HCl} 1 \%$ untuk menghilangkan kotoran dalam rumput laut dan melunakkan jaringan rumput laut lalu dilakukan pencucian dengan air bersih. Tahap selanjutnya adalah ekstraksi alginat dengan larutan $\mathrm{Na}_{2} \mathrm{CO}_{3} 2 \%$ (rasio 1:30) pada suhu $60-70{ }^{\circ} \mathrm{C}$ selama 60 menit dan selanjutnya dilakukan penggilingan. Setelah rumput laut digiling, selanjutnya diekstraksi selama 60 menit. Hasil ekstraksi disaring menggunakan vibrator dan penyaring 150 mesh. Filtrat yang dihasilkan ditambahkan $\mathrm{HCl} 10 \%$ hingga $\mathrm{pH}$ 2,8-3,2 sehingga terbentuk endapan asam alginat. Asam alginat lalu dipisahkan dan dicuci bersih. Asam alginat dinetralkan dengan $\mathrm{NaOH} 10 \%$ hingga $\mathrm{pH}$ 7. Setelah netral, filtrat dituang perlahan ke dalam larutan isopropil alkohol dengan rasio $1: 2(\mathrm{v} / \mathrm{v})$ dan diaduk perlahan serta dibiarkan selama 30 menit. Serat alginat yang terbentuk dikeringkan di bawah sinar matahari selama \pm 12 jam. Alginat yang dihasilkan kemudian dianalisis karakteristiknya, meliputi rendemen (AOAC, 2005), kadar air (BSN, 2015a) dan kadar abu (BSN, 2015b), dan pendugaan rasio $\mathrm{M} / \mathrm{G}$ (Manuronat/Guluronat) menggunakan Fourier Transform Infrared Spectroscopy (FTIR) (Spektrum one C69526) dengan metode yang mengacu pada Sakugawa, Ikeda, Takemura, dan Ono (2004).

\section{Pembuatan oligosakarida alginat (OSA)}

Pembuatan oligosakarida alginat (OSA) secara enzimatik dilakukan melalui depolimerisasi alginat dengan alginat liase komersial mengacu pada optimasi waktu yang telah dilakukan Subaryono, Peranginangin, Suhartono, dan Zakaria (2017) yaitu selama 8 jam pada suhu dan $\mathrm{pH}$ optimum sesuai saran penggunaan produsen (Sigma-Aldrich). Larutan alginat $0,1 \%$ sebanyak $4,5 \mathrm{~mL}$ ditambah enzim alginat liase sebanyak $0,15 \mathrm{~mL}$ dengan aktivitas $1 \mathrm{unit} / \mathrm{mL}$. Tiga cara penambahan enzim diterapkan sebagai perlakuan, yaitu (1) enzim ditambahkan sekali pada jam ke-0 dan diinkubasi selama 8 jam (Perlakuan E1); enzim ditambahkan setiap 2 jam inkubasi yaitu pada jam ke-0, ke-2, ke-4 dan ke-6 (Perlakuan E2), dan enzim ditambahkan setiap 4 jam inkubasi yaitu pada jam ke-0 dan ke-4 (Perlakuan E3). Total volume enzim dan aktivitasnya sama untuk setiap perlakuan. Campuran tersebut kemudian diinkubasi di dalam shaking incubator pada suhu $37^{\circ} \mathrm{C}$ selama total waktu 8 jam. Setelah diinkubasi, dilakukan pemanasan dengan air mendidih selama 10 menit untuk menghentikan aktivitas alginat liase diikuti dengan pengeringan menggunakan konsentrator pada suhu $37^{\circ} \mathrm{C}$. Oligosakarida alginat (OSA) yang dihasilkan kemudian dianalisis karakteristiknya meliputi kisaran derajat polimerisasi menggunakan Thin Layer Chromatography (TLC) (Subaryono et al., 2017), profil spektra FTIR (Mao, Zhang, Sun, \& Ren, 2012), dan kadar gula pereduksi menggunakan metode DNS (Li, Jiang, Guan, Wang, \& Guo, 2011).

\section{Pengujian aktivitas antioksidan}

Analisis aktivitas antioksidan dilakukan menggunakan metode DPPH (1,1-diphenyl-2picrylhydrazyl) yang mengacu pada Apak et al. (2013). Kontrol positif yang digunakan adalah larutan asam askorbat dengan konsentrasi 4, 6, 8 dan 10 ppm. Sampel dilarutkan dalam aquades dengan konsentrasi $1,2 \mathrm{mg} / \mathrm{mL}$ (1200 ppm). Sampel kemudian dimasukkan ke dalam microplate 96 sumur dengan proporsi 160 $\mu \mathrm{L}$ larutan sampel dan ditambahkan $40 \mu \mathrm{L}$ larutan DPPH (sampel), $160 \mu \mathrm{L}$ larutan sampel dan ditambahkan $40 \mu \mathrm{L}$ metanol (kontrol sampel), $160 \mu \mathrm{L}$ metanol dan ditambahkan $40 \mu \mathrm{L}$ larutan DPPH (kontrol negatif) serta $160 \mu \mathrm{L}$ metanol dan ditambahkan $40 \mu \mathrm{L}$ metanol (blanko). Microplate kemudian didiamkan selama 30 menit pada suhu ruang di dalam ruang gelap. Selanjutnya diukur nilai absorbansi sampel menggunakan spectrophotometer (Thermo scientific 1510) pada panjang gelombang $517 \mathrm{~nm}$. Aktivitas antioksidan dinyatakan dengan persen hambatan yang didapat dari nilai absorbansi sampel. Kemampuan menangkap radikal bebas (inhibisi) dihitung dengan rumus berikut ini :

$$
\underset{(\%)}{\operatorname{Inhibisi}}=\frac{\left(A_{\text {kontrol negatif }}-A_{\text {blanko }}\right)-\left(A_{\text {sampel }}-A_{\text {kontrol sampel }}\right)}{\left(A_{\text {kontrolnegatif }}-A_{\text {blanko }}\right)}
$$

\section{Pengujian aktivitas inhibitor $\alpha$ (alfa) glukosidase}

Analisis aktivitas inhibitor $\alpha$-glukosidase dilakukan terhadap sampel yang memiliki aktivitas antioksidan tertinggi, dibandingkan dengan alginat dalam bentuk polimer. Uji aktivitas ini mengacu pada metode Sancheti, Sancheti, dan Seo (2009). Sampel OSA 
diencerkan dalam aquades sampai konsentrasi 50 , $75,100,125$ dan 150 ppm serta dilakukan sonikasi untuk menghilangkan adanya gelembung udara. Larutan $\alpha$-glukosidase dibuat dengan mengencerkan 40 kali enzim dengan $0,1 \mathrm{M}$ buffer natrium fosfat, $\mathrm{pH}$ 6,9. Sebanyak $10 \mu \mathrm{L}$ larutan sampel dimasukkan ke dalam microplate, ditambahkan $50 \mu \mathrm{L}$ bufferfosfat, $25 \mu \mathrm{L}$ substrat PNPG (4-nitrophenyl $\alpha$-Dglucopyranoside) dan $25 \mu \mathrm{L}$ larutan enzim. Campuran diinkubasi pada $37^{\circ} \mathrm{C}$ selama 30 menit dan kemudian ditambahkan $100 \mu \mathrm{L} \mathrm{Na} \mathrm{CO}_{3}$ 0,2 M untuk menghentikan reaksi enzimatik. Absorbansi larutan diukur menggunakan ELISA reader (Epoch biotech) pada $\lambda 410 \mathrm{~nm}$. Penghambatan persen $\alpha$-glukosidase dihitung sebagai berikut:

$$
\underset{\alpha \text {-glukosidase }}{\text { \% inhibitor }}=100 \times\{1 \text { - ([glukosa] S / [glukosa] B) }\}
$$

di mana [glukosa] $\mathrm{S}$ dan [glukosa] B mewakili konsentrasi glukosa yang diproduksi dengan ada dan tidak adanya sampel uji. Nilai-nilai $I_{50}$ ditentukan dari persamaan regresi yang diperoleh dengan memasangkan data dari plot penghambatan persen a-glukosidase terhadap konsentrasi akarbosa 0,1 ; 0,$5 ; 1 ; 5$ dan 10 ppm (konsentrasi pengujian akhir). Akarbosa digunakan sebagai inhibitor referensi (kontrol positif).

\section{Analisis statistik}

Data yang diperoleh dianalisis menggunakan ANOVA $(p<0,05)$ dengan tiga kali pengulangan. Apabila terdapat perbedaan nyata antar perlakuan dilakukan uji lanjut Duncan menggunakan SPSS 21.0.

\section{HASIL DAN PEMBAHASAN}

\section{Karakteristik Alginat}

Karakteristik alginat yang dihasilkan disajikan pada Tabel 1. Rendemen alginat sebesar
$39,87 \pm 2,20 \%$, memenuhi spesifikasi yang ditetapkan Food Chemical Codex (FCC, 2004) yaitu lebih dari $20 \%$. Rendemen ini tidak jauh berbeda dengan hasil penelitian yang dilakukan Mushollaeni dan Rusdiana (2011) yaitu sebesar $30,3 \%$. Hasil rendemen yang cukup tinggi ini dapat disebabkan oleh habitat dan struktur $S$. crassifolium yang memiliki jumlah daun yang banyak. Kadar alginat di dalam daun alga coklat lebih tinggi daripada pada batang maupun akar (Mushollaeni \& Rusdiana, 2011). Selain itu metode ekstraksi alginat juga mempengaruhi rendemen alginat yang dihasilkan.

Hasil analisis kadar air alginat pada penelitian ini adalah sebesar $18,13 \pm 0,62 \%$. Hasil kadar air alginat masih cukup tinggi dibandingkan dengan standar Food Chemical Codex (FCC, 2004) yaitu kurang dari $15 \%$. Tingginya kadar air alginat pada penelitian ini mungkin disebabkan oleh proses pengeringan yang kurang optimal karena masih mengandalkan pengeringan menggunakan sinar matahari sehingga suhu pengeringan tidak dapat ditentukan. Selain itu konsentrasi isopropil alkohol yang telah jenuh juga dapat menyebabkan tingginya kadar air alginat pada penelitian ini, karena kemampuan mengikat airnya berkurang sehingga kadar air alginat menjadi tinggi. Kadar abu alginat dari S. crassifolium pada penelitian ini adalah 21,42 $\pm 0,64 \%$ lebih kecil dari hasil penelitian Sinurat dan Marliani (2017), namun masih memenuhi standar Food Chemical Codex (FCC, 2004) yaitu 13$27 \%$ (Tabel 1). Hasil kadar abu sangat dipengaruhi oleh jenis bahan baku rumput laut yang digunakan, proses ekstraksi alginat dan banyaknya zat pengotor yang masih terkandung dalam alginat. Rumput laut yang tumbuh di permukaan air dan tidak bersentuhan dengan dasar tanah memiliki kadar abu yang rendah karena akan sedikit zat pengotor seperti organisme berkapur yang tidak hilang saat pencucian (Chee, Wong, \& Wong, 2010).

Rasio MG dalam alginat akan mempengaruhi karakteristik OSA yang dihasilkan, karena sifat alginat

Tabel 1. Karakteristik alginat dari S. crassifolium

Table 1. Characteristics of alginate from $\underline{\text { S. crassifolium }}$

\begin{tabular}{lccc}
\hline \multicolumn{1}{c}{ Parameter/Parameters } & Hasil/Result & FCC (2004) & Pustaka/Reference \\
\hline Rendemen/Yield $(\%)$ & $39.87 \pm 2.20$ & $>20$ & $30.3^{\star}$ \\
Kadar air/Moisture (\%) & $18.13 \pm 0.62$ & $<15$ & - \\
Kadar abu/Ash content (\%) & $21.42 \pm 0.64$ & $13-27$ & $24.94-26.69^{\star *}$ \\
Rasio MG/MG Ratio & $0.93 \pm 0.43$ & - & $0.92 \pm 0.073^{\star * *}$ \\
\hline
\end{tabular}

Keterangan/Notes :

* : Mushollaeni \& Rusdiana (2011)

** : Sinurat \& Marliani (2017)

*** : Subaryono et al. (2017) 


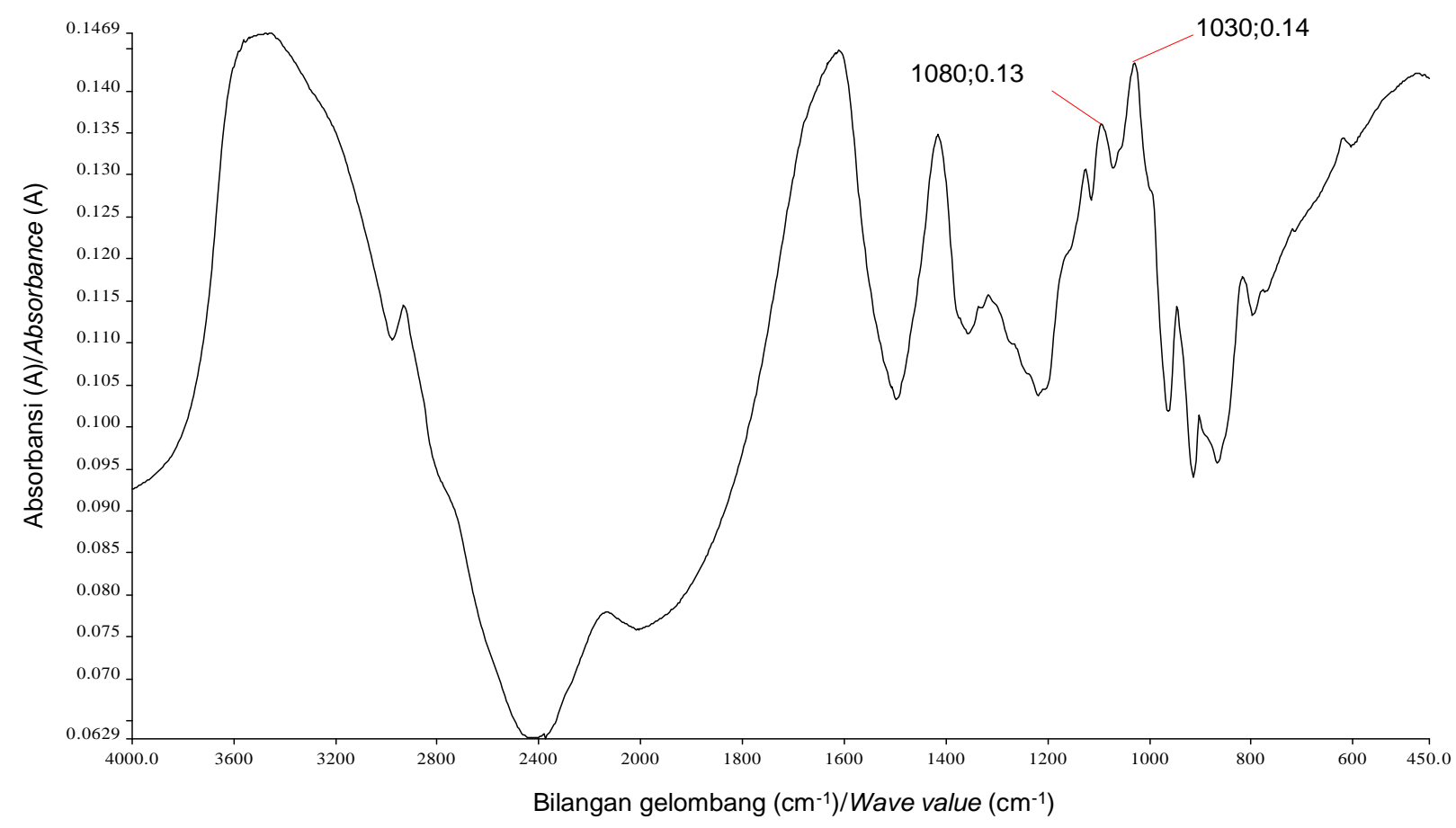

Gambar 1. Profil FTIR alginat dari S. crassifolium

Figure 1. FTIR profile of alginate from $\underline{\text { S. crassifolium }}$

liase memiliki aktivitas berbeda pada kondisi rasio $M G$ yang berbeda. Pendugaan rasio $M$ dan $G$ dilakukan dengan pendekatan rasio absorbansi FTIR pada bilangan gelombang 1030 dan $1080 \mathrm{~cm}^{-1}$ (Gambar 1). Bilangan gelombang $1030 \mathrm{~cm}^{-1}$ sebagai sidik jari polimanuronat dan bilangan gelombang $1080 \mathrm{~cm}^{-1}$ sebagai sidik jari poliguluronat (Subaryono et al., 2017). Hasil perbandingan absorbansi tersebut kemudian disubstitusikan dalam persamaan hubungan rasio absorbansi dengan proporsi MG dalam sampel yang telah diketahui nilainya (Sakugawa et al., 2004). Dari perhitungan diperoleh hasil pendugaan rasio MG alginat pada penelitian ini sebesar $0,93 \pm 0,43$ dengan proporsi polimanuronat dan poliguluronat masingmasing sebesar $47,16 \pm 8,22 \%$ dan $52,84 \pm 8,22 \%$. Sen (2011) menyatakan bahwa alginat yang berasal dari Sargassum sp. biasanya memiliki rasio MG yang rendah $(<1,00)$. Proporsi $M$ dan $\mathrm{G}$ ini tidak hanya tergantung pada spesies rumput laut coklat yang digunakan tetapi juga dipengaruhi oleh musim, umur dan sumber rumput laut coklat (Bertagnolli, Espindola, Kleinübing, Tasic \& Silva, 2014).

\section{Rendemen Oligosakarida Alginat (OSA)}

Rendemen OSA yang dihasilkan berkisar antara $77,29 \pm 1,97 \%$ hingga $85,46 \pm 9,15 \%$ (Tabel 2). Hasil analisis RAL dengan selang kepercayaan 95\% menunjukkan bahwa cara penambahan enzim tidak berpengaruh nyata terhadap rendemen OSA yang dihasilkan $(P>0,05)$ sehingga penambahan enzim 1 kali pada awal proses perlu dipertimbangkan karena lebih efisien.

Rendemen OSA jauh lebih besar jika dibandingkan dengan penelitian yang dilakukan Afni (2017) yaitu sebesar $38,33 \pm 2,88 \%$ dengan menggunakan alginat liase yang diperoleh dari Bacillus megaterium dan aktivitas enzim sebesar $100 \mathrm{U}$ serta substrat yang

Tabel 2. Rendemen oligosakarida alginat Table 2. Alginate oligosaccharides yield

\begin{tabular}{lc}
\hline \multicolumn{1}{c}{ Penambahan Enzim/Enzyme Addition } & Rendemen/Yield (\%) \\
\hline 1 kali/1 time (E1) & $85.46 \pm 9.15 \mathrm{a}$ \\
Setiap 2 jam/Every 2 hours (E2) & $83.42 \pm 7.61 \mathrm{a}$ \\
Setiap 4 jam/Every 4 hours (E3) & $77.29 \pm 1.97 \mathrm{a}$ \\
\hline
\end{tabular}


digunakan adalah larutan alginat 5\%. Li et al. (2016) menyatakan bahwa rendemen OSA dipengaruhi oleh aktivitas dan spesifikasi kerja alginat liase yang digunakan. Selain itu, rendemen OSA yang dihasilkan sangat tergantung dengan rasio $M G$ alginat yang digunakan (Ramnani et al., 2012).

\section{Kadar gula pereduksi}

Gula pereduksi merupakan kelompok gula yang yang dapat mereduksi senyawa-senyawa penerima elektron melalui mekanisme reaksi reduksi-oksidasi. Gula pereduksi ditandai dengan adanya gugus hidroksil bebas pada C1. Gula pereduksi biasanya dihasilkan dari proses pemecahan gula kompleks menjadi gula sederhana yang dilakukan secara fisik, enzimatis maupun kimiawi. Zhu et al. (2016) menyatakan bahwa untuk melihat efektivitas depolimerisasi alginat melalui proses enzimatik dapat dilihat dari kadar gula pereduksi yang dihasilkan.

Hasil analisis ragam dengan selang kepercayaan 95\% menunjukkan bahwa cara penambahan enzim (sekaligus ataupun secara bertahap) pada proses depolimerisasi alginat menjadi OSA menggunakan alginat liase tidak berpengaruh nyata $(P>0,05)$ terhadap kadar gula pereduksi OSA yang dihasilkan. Dengan demikian alginat liase lebih efisien ditambahkan 1 kali di awal proses depolimerisasi (Gambar 2). Hasil ini juga memperlihatkan bahwa selama proses depolimerisasi kerja alginat liase stabil sehingga efek alosterik tidak mempengaruhi kerja enzim alginat liase. Beberapa faktor yang dapat mempengaruhi kerja alginat liase adalah spesifikasi enzim yang digunakan (Kim et al., 2011), sehingga apabila spesifikasi alginat liase yang digunakan sama seperti jumlah, aktivitas dan sumbernya, maka akan dihasilkan produk yang sama. Hal ini yang mungkin menyebabkan kadar gula pereduksi antar perlakuan tidak berbeda nyata.

\section{Derajat Polimerisasi (DP)}

Pengujian derajat polimerisasi OSA dilakukan untuk mengetahui perkiraan derajat polimerisasi OSA yang dihasilkan selama proses depolimerisasi. Pemotongan polimer alginat setelah proses depolimerisasi alginat dari polimer besar menjadi unit yang lebih kecil dapat dengan melihat nilai $\mathrm{Rf}$ (Retention factor) spot yang terbentuk.

Zimogram TLC menunjukkan bahwa spot yang terbentuk pada OSA E1, E2 dan E3 mengalami peningkatan nilai $\mathrm{Rf} j \mathrm{jika}$ dibandingkan dengan nilai $\mathrm{Rf}$ alginat. Hal ini membuktikan bahwa telah terjadi pemotongan polimer alginat menjadi unit yang lebih kecil. Proses pemotongan polimer alginat ditunjukkan dengan semakin meningkat nilai Rf spot TLC yang menunjukkan semakin kecil ukuran polimer yang terbentuk selama proses depolimerisasi (Falkeborg et al., 2014).

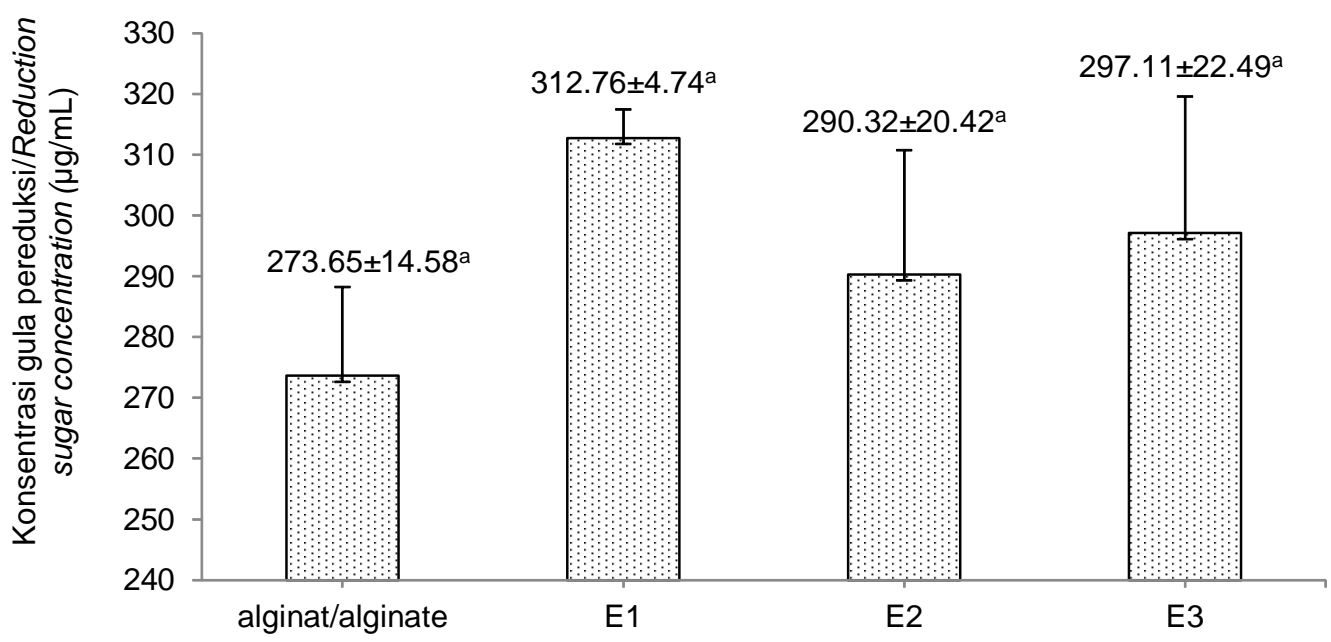

Keterangan/Notes:

E1 : Perlakuan 1 kali penambahan enzim/1 time enzyme addition

E2 : Perlakuan penambahan enzim setiap 2 jam/Enzyme addition every 2 hours

E3 : Perlakuan penambahan enzim setiap 4 jam/Enzyme addition every 4 hours

Gambar 2. Kadar gula pereduksi oligosakarida alginat

Figure 2. Reducing sugar content of alginate oligosaccharides 
Tabel 3. Nilai Retention factor zimogram TLC oligosakarida alginat Table 3. Retention factor TLC zimogram of alginate oligosaccharides

\begin{tabular}{lcc}
\hline \multicolumn{1}{c}{ Penambahan Enzim/Enzyme Addition } & Spot & Rf \\
\hline Alginat/Alginate & 1 & 0 \\
\hline \multirow{2}{*}{ kali/1 time (E1) } & 1 & 0.27 \\
& 2 & 0.34 \\
\hline \multirow{2}{*}{ Setiap 2 jam/Every 2 hours (E2) } & 1 & 0.17 \\
& 2 & 0.23 \\
& 3 & 0.29 \\
Setiap 4 jam/Every 4 hours (E3) & 4 & 0.37 \\
\hline Manosa/Manose & 1 & 0.23 \\
\hline
\end{tabular}

Standar marker yang digunakan adalah manosa yang merupakan monosakarida yang memiliki DP 1 . Nilai Rf spot OSA E1, E2 dan E3 yang terbentuk lebih kecil dari manosa (Tabel 3) namun di atas alginat sehingga kemungkinan DP yang terbentuk di atas 1 menandakan telah terbentuk oligosakarida selama proses depolimerisasi alginat. Liu et al. (2019) menyatakan bahwa OSA biasanya terdiri dari 2-25 monomer sehingga OSA yang dihasilkan telah memenuhi syarat monomer OSA.

Jika dilihat dari spot yang terbentuk (Gambar 3), penambahan enzim setiap 2 jam sekali (E2) menghasilkan OSA dengan DP terendah lebih banyak jika dibandingkan dengan perlakuan lain yaitu pada spot ke-4 dengan Rf 0,37. Pada hasil perlakuan penambahan enzim 1 kali (E1) dan penambahan enzim setiap 4 jam (E3) masih terdapat OSA dengan DP tinggi ( $R f$ rendah) yang terlihat dari adanya bercak memanjang (ekor) OSA yang terbentuk di bagian bawah, sedangkan pada perlakuan E2 tidak ada lagi bercak memanjang OSA di bagian bawah mendekati garis awal. Hal ini memperlihatkan bahwa penambahan enzim secara berkala dapat menghasilkan perbedaan proporsi DP OSA. Perlakuan

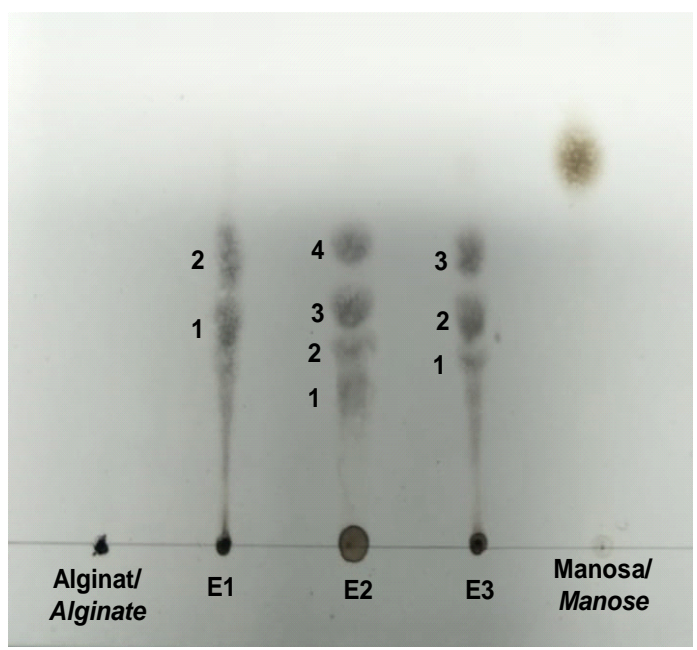

Keterangan/Notes:

E1 : Perlakuan 1 kali penambahan enzim/1 time enzyme addition

E2 : Perlakuan penambahan enzim setiap 2 jam/Enzyme addition every 2 hours

E3 : Perlakuan penambahan enzim setiap 4 jam/Enzyme addition every 4 hours

Gambar 3. Zimogram TLC oligosakarida alginat

Figure 3. TLC zimogram of alginate oligosaccharides 
E1 menghasilkan proporsi OSA dengan DP tinggi (OSA rantai panjang) yang lebih banyak jika dibandingkan dengan E2 dan E3, sebaliknya hasil perlakuan E2 mengandung proporsi OSA dengan DP rendah (OSA rantai pendek) yang lebih banyak jika dibandingkan dengan E1 dan E3. Sedangkan perlakuan E3 menghasilkan OSA dengan rantai pendek yang lebih banyak dari OSA rantai panjang. Tiga perlakuan ini menghasilkan OSA dengan DP terkecil yang tidak berbeda jika dilihat dari $\mathrm{Rf}$ spot terjauh yaitu 0,34 (E1), 0,37 (E2) dan 0,36 (E3) sehingga rata-rata ketiga perlakuan tersebut menghasilkan OSA dengan DP terendah yang sama namun dengan jumlah/proporsi yang berbeda. Subaryono (2016) menyatakan bahwa kisaran DP OSA dapat dipengaruhi oleh aktivitas enzim, semakin tinggi aktivitasnya maka proses depolimerisasi alginat semakin efektif dan banyak menghasilkan OSA dengan DP rendah. Penelitian ini menggunakan aktivitas enzim yang sama sehingga kisaran DP terendah yang dihasilkan sama dan cara penambahan enzim yang berbeda-beda menyebabkan proporsi DP OSA berbeda.

\section{Profil FTIR OSA}

Pengujian profil FTIR dilakukan untuk mengetahui perbedaan struktur alginat yang terjadi selama proses depolimerisasi. Profil FTIR memperlihatkan perubahan intensitas penyerapan gugus fungsi pada alginat dan OSA. Maharani, Husni, dan Ekantari (2017) menyatakan bahwa alginat memiliki puncak spesifik tertentu pada FTIR yaitu gugus hidroksil pada bilangan gelombang sekitar $3500 \mathrm{~cm}^{-1}$, COO simetris pada bilangan gelombang sekitar $1410 \mathrm{~cm}^{-1}$ dan COO asimetris pada bilangan gelombang $1620 \mathrm{~cm}^{-1}$. Alginat terdiri dari monomer manuronate dan guluronat.

Hasil pengujian FTIR alginat dan OSA menunjukkan terjadinya beberapa perubahan serapan selama proses depolimerisasi alginat namun OSA E1, E2 dan E3 tidak ada perbedaan serapan yang signifikan satu sama lain (Tabel 4). Serapan OSA E1, E2 dan E3 pada bilangan gelombang $3500 \mathrm{~cm}^{-1}$ yang menunjukkan keberadaan gugus hidroksil $(-\mathrm{OH})$ mengalami peningkatan intensitas penyerapan jika dibandingkan dengan alginat yang belum mengalami depolimerisasi. Peningkatan intensitas serapan -OH pada OSA disebabkan oleh konsentrasi $-\mathrm{OH}$ yang semakin meningkat. Dompeipen (2017) menyatakan bahwa penurunan intensitas serapan gugus fungsi pada spektra FTIR menunjukkan adanya penurunan konsentrasi gugus fungsi. Selama proses depolimerisasi terjadi pemutusan ikatan glikosidik antara gugus $\mathrm{OH}$ pada $\mathrm{C} 1$ dan $\mathrm{C} 4$ pada monomer alginat oleh alginat liase sehingga masing-masing

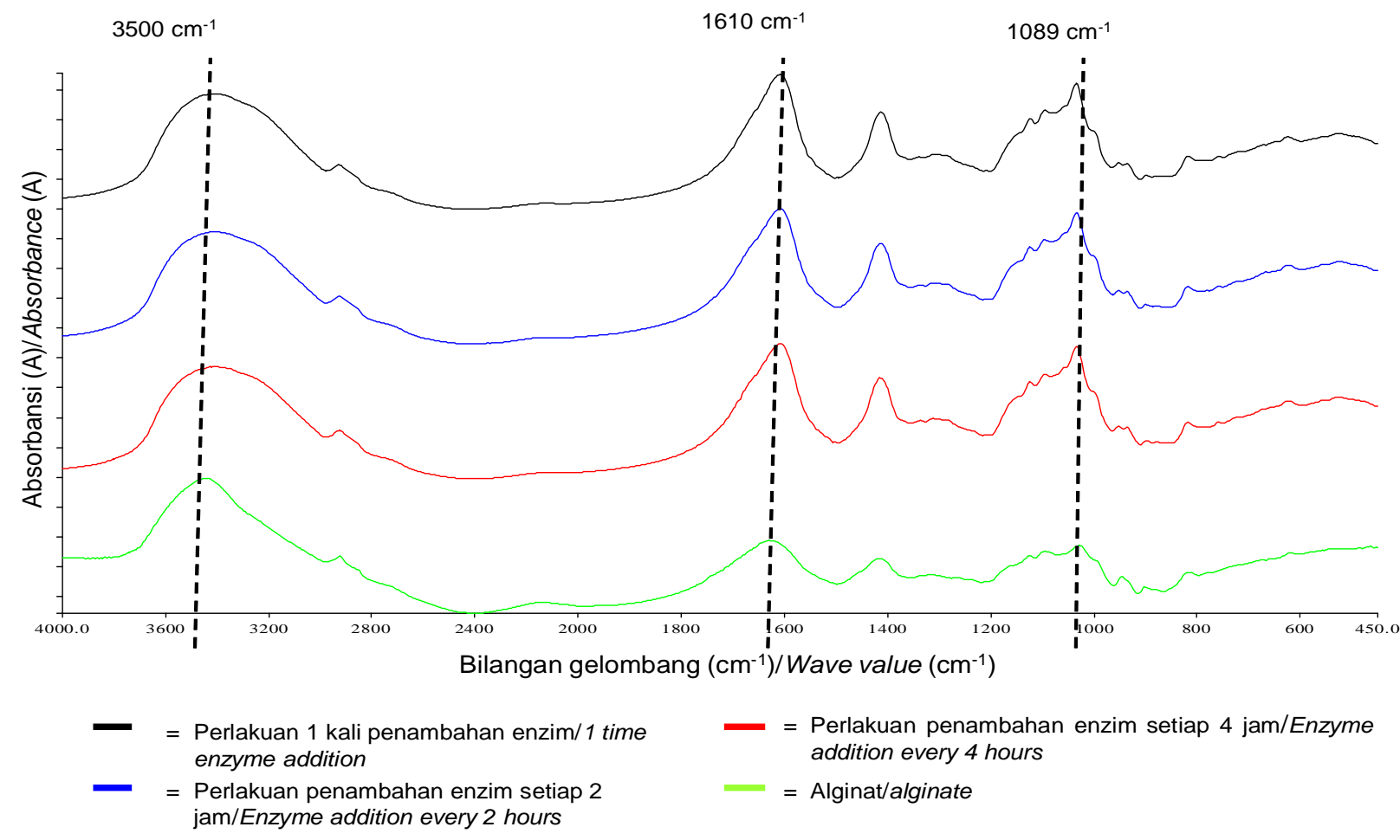

Gambar 4. Profil FTIR oligosakarida alginat

Figure 4. FTIR profile of alginate oligosaccharides 
Tabel 4. Nilai absorbansi FTIR oligosakarida alginat

Table 4 FTIR absorbance of alginate oligosaccharides

\begin{tabular}{lcc}
\hline Penambahan Enzim/Enzyme Addition & $\begin{array}{c}\text { Absorbansi di } \mathbf{3 5 0 0} \mathbf{~ c m - 1 /} \\
\text { Absorbance in } \mathbf{3 5 0 0} \mathbf{~ c m - 1}\end{array}$ & $\begin{array}{c}\text { Rasio A1089/A1610/ } \\
\text { A 1089/ A 1610 Ratio }\end{array}$ \\
\hline Alginat/Alginate & 0.147 & 1.037 \\
1 kali/1 time (E1) & 0.822 & 0.747 \\
setiap 2 jam/Every 2 hours (E2) & 0.711 & 0.783 \\
setiap 4 jam/Every 4 hour (E3) & 0.725 & 0.790 \\
\hline
\end{tabular}

monomer yang terbentuk akan membentuk gugus $\mathrm{OH}$ kembali. Hal ini menyebabkan peningkatan konsentrasi-OH pada OSA E1, E2 dab E3.

Pemutusan ikatan glikosidik selama proses depolimerisasi juga dapat dilihat dari rasio absorbansi pada bilangan gelombang $1089 \mathrm{~cm}^{-1}$ dan $1610 \mathrm{~cm}^{-1}$ $\left(A_{1089} / A_{1610}\right)$. Mao et al. (2012) menyatakan bahwa rasio $A_{1089} / A_{1610}$ sebagai puncak kelompok C-O-C dan gugus hidroksil yang mengalami penurunan disebabkan oleh adanya pemutusan ikatan glikosidik. Rasio $A_{1089} / A_{1610}$ OSA E1, E2 dan E3 mengalami penurunan jika dibandingkan dengan alginat asli. Hal ini memperlihatkan bahwa telah terjadi pemutusan ikatan glikosidik selama proses depolimerisasi alginat menggunakan alginat liase.

\section{Aktivitas Antioksidan OSA}

Antioksidan merupakan senyawa yang dapat mencegah terjadinya reaksi oksidasi dengan cara menyumbangkan elektronnya kepada radikal bebas sehingga dapat mengatasi kelebihan radikal bebas didalam tubuh. Penderita diabetes sangat mudah mengalami kondisi stress oksidatif karena tingginya kadar glukosa didalam darah (Tiwari et al.,2013). Mengkonsumsi senyawa yang memiliki aktivitas sebagai antioksidan merupakan salah satu terapi yang dapat menurunkan resiko stress oksidatif pada penderita diabetes.
Pengujian aktivitas antioksidan dilakukan terhadap alginat dan OSA untuk mengetahui perbedaan aktivitas antioksidan alginat sebelum dan sesudah depolimerisasi. Aktivitas antioksidan OSA E1 dan E3 lebih tinggi jika dibandingkan dengan alginat, sedangkan aktivitas OSA E2 tidak berbeda nyata dengan alginat. Nilai persen hambatan alginat sebesar $32,50 \pm 2,16 \%$ sedangkan nilai persen hambatan OSA E1 dan E3 berturut-turut sebesar $41,22 \pm 2,03 \%$ dan $38,52 \pm 0,32 \%$. Hal ini memperlihatkan bahwa proses depolimerisasi alginat menjadi oligosakarida alginat (OSA) dapat meningkatkan aktivitasnya sebagai antioksidan. Hasil penelitian ini serupa dengan penelitian yang dilakukan Falkeborg et al. (2014), alginat yang telah mengalami depolimerisasi memiliki aktivitas antioksidan yang lebih tinggi dibandingkan dengan alginat sebelum depolimerisasi.

Hasil analisis ragam dengan selang kepercayaan 95\% menunjukkan bahwa cara penambahan alginat liase pada proses depolimerisasi alginat berpengaruh nyata $(p<0,05)$ terhadap aktivitas antioksidan OSA yang dihasilkan. Penambahan enzim 1 kali (E1) menghasilkan OSA dengan aktivitas antioksidan paling tinggi dibandingkan dengan perlakuan lainnya yaitu dengan penghambatan sebesar $41,22 \pm 2,03 \%$ pada konsentrasi $1,2 \mathrm{mg} / \mathrm{mL}$. Struktur kimia mungkin merupakan faktor penting yang mempengaruhi aktivitas antioksidan ini. Ueno dan Oda (2014) menyatakan bahwa perubahan struktur kimia pada

Tabel 5. Aktivitas antioksidan oligosakarida alginat pada konsentrasi $1.2 \mathrm{mg} / \mathrm{mL}$

Table 5. Antioxidant activity of alginate oligosaccharides at $1.2 \mathrm{mg} / \mathrm{mL}$

\begin{tabular}{lc}
\hline Penambahan Enzim/Enzyme Addition & Penghambatan/inhibition (\%) \\
\hline Alginat/Alginate & $32.69 \pm 2.16 \mathrm{a}$ \\
1 kali/ 1 time (E1) & $41.22 \pm 2.03 \mathrm{c}$ \\
setiap 2 jam/Every 2 hours (E2) & $34.27 \pm 1.57 \mathrm{ab}$ \\
setiap 4 jam/Every 4 hours (E3) & $38.52 \pm 0.32 \mathrm{bc}$ \\
\hline
\end{tabular}


senyawa polisakarida akan mempengaruhi aktivitasnya sebagai antioksidan. Oligosakarida alginat E1 mengandung proporsi OSA rantai panjang yang lebih banyak daripada OSA E2 dan E3 jika dilihat dari hasil TLC (Gambar 3). Hasil penelitian ini sesuai dengan penelitian Yudiati, Pringgenies, Djunaedi, Arifin, dan Sudaryono (2018) yang menunjukkan bahwa depolimerisasi alginat menggunakan panas menghasilkan OSA dengan aktivitas antioksidan yang lebih tinggi pada OSA dengan berat molekul lebih tinggi dibandingkan dengan OSA dengan berat molekul rendah. Hasil serupa dilaporkan oleh Chattopadhyay et al. (2010) yang menyatakan bahwa polisakarida dari rumput laut coklat dengan berat molekul yang lebih tinggi (rantai panjang) memiliki aktivitas antioksidan yang lebih baik jika dibandingkan dengan polisakarida rumput laut coklat (Laminaran) rantai pendek. Hasil yang berbeda ditemukan oleh Falkeborg et al. (2014) yang menyatakan bahwa OSA yang memiliki berat molekul lebih besar (OSA rantai panjang) memiliki aktivitas antioksidan lebih rendah dibandingkan dengan asam guluronat yang merupakan oligosakarida rantai pendek pada alginat. Proses depolimerisasi secara enzimatik dapat mendegradasi polisakarida alginat dengan berat molekul tinggi menjadi oligosakarida alginat dengan berat molekul rendah namun hasil penelitian ini memperlihatkan bahwa cara penambahan enzim berpengaruh terhadap proporsi rantai OSA yang dihasilkan. Penambahan enzim secara sekaligus atau bertahap menghasilkan proporsi OSA rantai panjang dan pendek yang berbeda-beda. Perbedaan proporsi OSA rantai pendek dan panjang ini diduga menyebabkan perbedaan aktivitas antioksidan OSA yang dihasilkan.

Aktivitas antioksidan OSA pada penelitian ini tergolong tinggi jika dibandingkan dengan penelitian yang telah dilakukan sebelumnya. Zhu et al. (2016) menyatakan bahwa oligosakarida alginat hasil depolimerisasi dengan alginat liase memiliki aktivitas antioksidan sebesar $81,0 \%$ dengan konsentrasi OSA $18 \mathrm{mg} / \mathrm{mL}$. Penelitian Wang et al. (2007) menghasilkan OSA dengan aktivitas antioksidan mencapai $64 \%$ pada konsentrasi $6,5 \mathrm{mg} / \mathrm{mL}$. Hasil aktivitas antioksidan OSA E1 pada penelitian ini tidak jauh berbeda dengan penelitian yang dilakukan Falkeborg et al. (2014) yang menghasilkan OSA dengan aktivitas antioksidan sebesar $95,5 \%$ pada konsentrasi OSA 3,13 mg/mL.

Meskipun aktivitas antioksidan polisakarida telah banyak terbukti, dan beberapa penelitian menyatakan bahwa struktur kimia dan berat molekul dari polisakarida sangat berpengaruh terhadap aktivitasnya sebagai antioksidan (Ueno \& Oda 2014) namun hubungan antara struktur polisakarida khususnya alginat dan aktivitas antioksidan belum dapat dijelaskan. Chattopadhyay et al. (2010) menyatakan bahwa hal ini disebabkan oleh beberapa faktor penting. Pertama, keragaman struktur dan sumber dari polisakarida sehingga sulit untuk menentukan hubungan antara struktur dan aktivitas antioksidan. Kedua, banyak polisakarida yang masih mengandung sejumlah molekul lain seperti pigmen, protein atau peptida sehingga memengaruhi aktivitasnya

\section{Aktivitas OSA sebagai Inhibitor $\alpha$-glukosidase}

Alfa glukosidase merupakan enzim golongan hidrolase yang berfungsi memecah karbohidrat pada usus halus manusia. Enzim ini mengkatalisis hidrolisis ikatan $\alpha-1,4$ sehingga menghasilkan $\alpha$-D glukosa (Tundis, Loizzo, \& Menichini, 2010). Enzim ini berperan penting dalam penyerapan glukosa ke dalam darah yang menyebabkan peningkatan glukosa darah pada penderita diabetes. Penghambatan $\alpha$-glukosidase telah banyak dilakukan pada penderita diabetes untuk menurunkan tingkat penyerapan glukosa di dalam darah sehingga dapat mengendalikan kadar glukosa di dalam darah. Pengujian aktivitas inhibitor $\alpha$-glukosidase dilakukan terhadap OSA yang memiliki aktivitas antioksidan terbaik (OSA E1) serta alginat sebelum mengalami proses depolimerisasi dan akarbosa sebagai kontrol positif.

Hasil pengujian aktivitas OSA E1 sebagai inhibitor $\alpha$-glukosidase menunjukkan bahwa OSA E1 memiliki aktivitas yang lebih rendah dibandingkan dengan alginat yang belum mengalami depolimerisasi dengan nilai $\mathrm{IC}_{50}$ alginat sebesar $5,27 \pm 0,29$ dan OSA E1 sebesar $11,23 \pm 4,17 \mathrm{ppm}$ (Tabel 6). Aktivitas inhibitor $\alpha$-glukosidase alginat hasil penelitian ini yaitu $93,46 \pm 1,04 \%$ pada konsentrasi 150 ppm (Gambar 5) lebih tinggi jika dibandingkan dengan penelitian yang dilakukan Samudra, Sani, dan Husni (2017), yang menunjukkan bahwa aktivitas inhibitor $\alpha$-glukosidase alginat sebesar $58,75 \%$ pada konsentrasi $2 \mathrm{mg} / \mathrm{mL}$ (2000 ppm). Aktivitas inhibitor $\alpha$-glukosidase alginat yang lebih tinggi daripada OSA E1 memperlihatkan bahwa proses depolimerisasi alginat tidak menyebabkan aktivitas inhibitor $\alpha$-glukosidase meningkat. Hal ini kemungkinan besar disebabkan oleh perubahan struktur alginat selama proses depolimerisasi, sebagaimana dilaporkan Shan et al. (2015) yang melakukan penelitian hampir sama, dari fukoidan. Fukoidan sebagai polisakarida dari rumput laut coklat yang secara bergantian dihubungkan dengan ikatan glikosidik $(1 \longrightarrow 3)$ dan $(1 \longrightarrow 4)$ memiliki aktivitas $\alpha$-glukosidase yang lebih tinggi daripada fukoidan yang dihubungkan hanya dengan ikatan glikosidik $(1 \rightarrow 3)$. Hal ini membuktikan bahwa struktur polisakarida dapat mempengaruhi aktivitas inhibitor $\alpha$-glukosidase. 
Tabel 6. Aktivitas inhibitor $\alpha$-glukosidase oligosakarida alginat, alginat dan akarbosa Table 6. $\alpha$-glukosidase inhibitor activity of alginate oligosaccharides, alginate and acarbose

\begin{tabular}{lc}
\hline \multicolumn{1}{c}{ Sampel/Sample } & IC50 (ppm)//C50 (ppm) \\
\hline Akarbosa (kontrol positif)/Acarbose (Positive Control) & $0.32 \pm 0.02$ \\
Alginat/Alginate & $5.27 \pm 0.29$ \\
OSA 1 kali penambahan enzim (E1)/ AOS 1 time enzym addition (E1) & $11.23 \pm 4.17$ \\
\hline
\end{tabular}

Alginat yang memiliki monomer asam guluronat dapat membentuk gel dengan membentuk jaring-jaring seperti "egg box" antar monomer guluronat. Jaringjaring ini yang dapat mengikat molekul air dengan kuat sehingga terbentuklah tekstur gel. Samudra et al.(2017) menyatakan bahwa jaring-jaring pada alginat ini dapat menjerat substrat dan enzim dengan baik sehingga substrat dan enzim yang terjerat tidak dapat bereaksi satu sama lain, jika hal ini terjadi maka enzim $\alpha$-glukosidase tidak dapat mengubah polisakarida menjadi gula sederhana dan peningkatan glukosa dalam darah dapat dicegah. Kemampuan membentuk gel alginat yang telah mengalami depolimerisasi (OSA) akan berkurang karena ikatan glikosidik $(1 \rightarrow 4)$ telah banyak diputus sehingga sulit untuk membentuk jejaring "egg box".

\section{KESIMPULAN}

Proses depolimerisasi alginat menjadi OSA menggunakan alginat liase dapat mengubah karakteristik polisakarida tersebut. Cara penambahan enzim (sekaligus ataupun secara bertahap) pada proses depolimerisasi alginat menjadi OSA menghasilkan proporsi OSA rantai panjang dan pendek yang berbeda-beda. Penambahan enzim secara sekaligus menghasilkan OSA dengan proporsi rantai panjang lebih banyak dan kadar gula pereduksi yang tidak jauh berbeda dari OSA hasil perlakuan penambahan enzim secara bertahap. Proses depolimerisasi ini juga menyebabkan perubahan aktivitas antioksidan dan inhibitor $\alpha$-glukosidase. Aktivitas antioksidan OSA E1 lebih tinggi jika

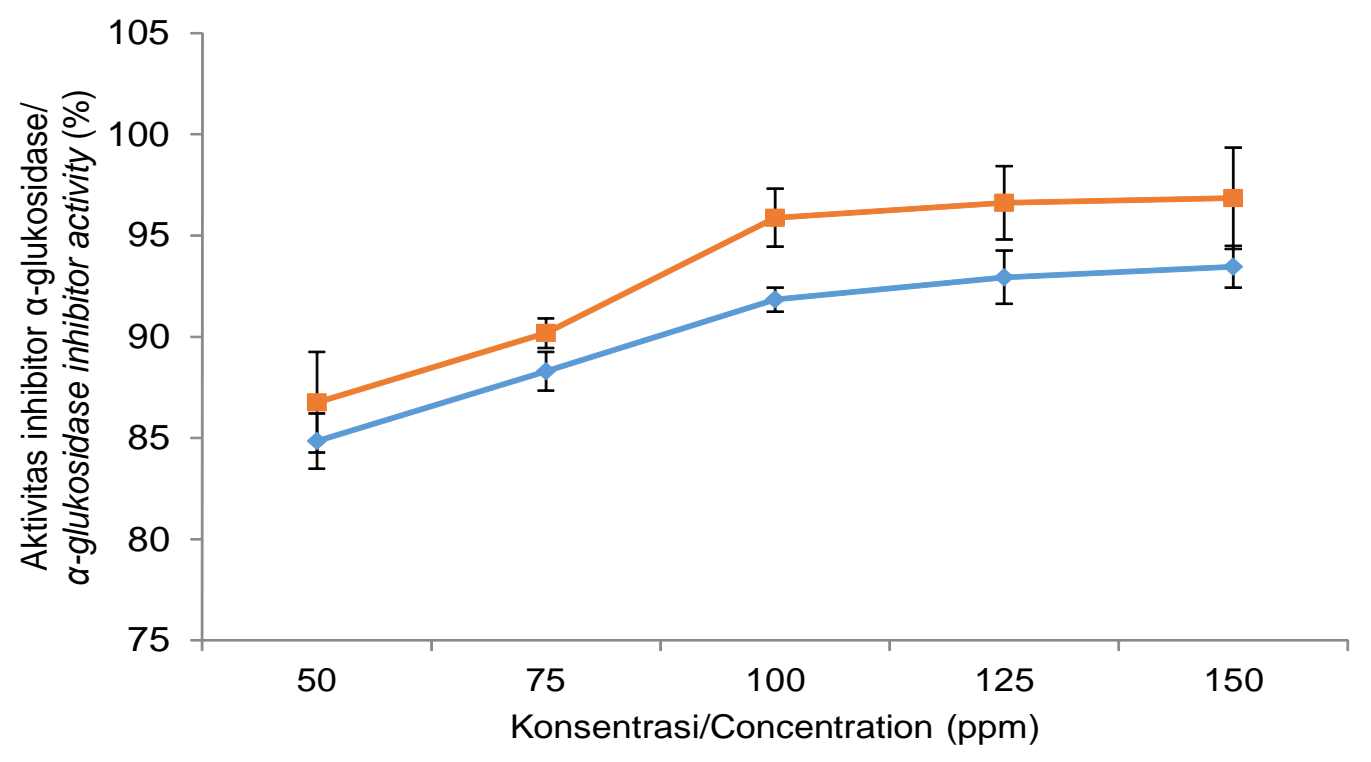

$\because$ OSA E1 $\quad-$ Alginat/Alginate

Keterangan/Note: OSA E1 (perlakuan 1 kali penambahan enzim/1 time adding enzymes treatment)

Gambar 5. Aktivitas Inhibitor $\alpha$-glukosidase alginat dan oligosakarida alginat

Figure 5. $\alpha$-glukosidase inhibitor activity of alginate and alginate oligosaccharides 
dibandingkan dengan alginat, dengan penghambatan terhadap DPPH sebagai radikal bebas sebesar $41,22 \pm 2,03 \%$ pada konsentrasi $1,2 \mathrm{mg} / \mathrm{mL}$. Aktivitas inhibitor $\alpha$-glukosidase OSA E1 lebih kecil dibandingkan dengan polimer alginat dengan nilai $\mathrm{IC}_{50}$ masing-masing sebesar $11,23 \pm 4,17 \mathrm{ppm}$ dan $5,27 \pm 0,29 \mathrm{ppm}$. Proses depolimerisasi alginat meningkatkan aktivitasnya sebagai antioksidan namun tidak meningkatkan aktivitasnya sebagai inhibitor $\alpha$-glukosidase.

\section{UCAPAN TERIMA KASIH}

Terima kasih diberikan kepada Balai Besar Riset Pengolahan Produk dan Bioteknologi Kelautan dan Perikanan (BBRP2BKP) yang telah memberikan dana hibah untuk penelitian ini, para peneliti dan teknisiteknisi laboratorium pengolahan, kimia, instrumen dan bioteknologi BBRP2BKP yang telah membantu proses penelitian ini.

\section{DAFTAR PUSTAKA}

Afni, F. S. (2017). Produksi alginate oligosaccharides (AOS) sebagai bahan prebiotik menggunakan enzim alginat liase. Tesis. Institut Pertanian Bogor, Bogor.

Association Official Analytical Chemist's Technical Standard (AOAC). (2005). Official Methods of Analysis, 16th ed. Washington (US): Association Official Analytical Chemist's Technical Standard.

Apak, R., Gorinstein, S., Bohm, V., Schaich, K. M., Ozyurek, M., \& Goclu, K. (2013). Methods od measurement and evaluation of natural antioxidant capacity activity (IUPAC technical report). Pure and Applied Chemistry, 85(5), 958-998.

Bertagnolli, C., Espindola, A. P. D. M., Kleinübing, S. J., Tasic, L., \& Silva, M. G. C. (2014). Sargassum filipendula alginate from Brazil: Seasonal influence and characteristics. Carbohydrate Polymers, 111, 619-623. doi:10.1016/j.carbpol.2014.05.024.

Badan Standardisasi Nasional (BSN). (2015a). Pengujian kadar air pada produk perikanan SNI 2354.2:2015. Jakarta, ID: Badan Standardisasi Nasional

Badan Standardisasi Nasional (BSN). (2015b). Pengujian kadar abu pada produk perikanan SNI 2354.1:2015. Jakarta, ID: Badan Standardisasi Nasional.

Chattopadhyay, N., Ghosh, T., Sinha, S., Chattopadhyay, K., Karmakar, P., \& Ray, B. (2010). Polysaccharides from Turbinaria conoides: structural features and antioxidant capacity. Food chemistry, 118(3), 823-829.

Chee, S. Y., Wong, P. K., \& Wong, C. L. (2010). Extraction and characterisation of alginate from brown seaweeds (Fucales, Phaeophyceae) collected from Port Dickson, Peninsular Malaysia. Journal of Applied Phycology, 23(2), 191-196. doi:10.1007/s10811-0109533-7.
Dompeipen, E. J. (2017). Isolasi dan identifikasi kitin dan kitosan dari kulit udang windu (Penaeus monodon) dengan spektroskopi inframerah. Majalah BIAM, 13(1), 31-41.

Falkeborg, M., Cheong, L. Z., Gianfico, C., Sztukiel, K. M., Kristensen, K., Glasius, M., ... Guo, Z. (2014). Alginate oligosaccharides: Enzymatic preparation and antioxidant property evaluation. Food Chemistry, 164, $185-194$.ht t ps://doi.org/10.1016/ j.foodchem.2014.05.05

Fatmawati, A., Agustriyanto, R., \& Liasari, Y. (2013). Enzymatic hydrolysis of alkaline pretreated coconut coir. Bulletin of hemical Reaction Engineering \& Catalysis, 8(1), 34-39.

Food Chemical Codex (FCC) . (2004). Food Chemical Codex. 5th ed. National Academic of Science. Washington DC. (5):155-195

Hao, J., Hao, C., Zhang, L., Liu, X., Zhou, X., Dun, Y., ... Yu, G. (2015). OM2, a novel oligomannuronate-chromium (III) complex, promotes mitochondrial biogenesis and lipid metabolism in 3T3-L1 adipocytes via the AMPKPGC1a pathway. PLoS ONE, 10(7). https://doi.org/ 10.1371/journal.pone.0131930

Husni, A., Subaryono, Pranoto, Y., Tazwir, \& Ustadi. (2012). Pengembangan metode ekstraksi alginat dari rumput laut Sargassum sp. sebagai bahan pengental, AGRITECH, 32(1), 1-8.

Iwamoto, M., Kurachi, M., Nakashima, T., Kim, D., Yamaguchi, K., Oda, T., ... Muramatsu, T. (2005). Structure-activity relationship of alginate oligosaccharides in the induction of cytokine production from RAW 264.7 cells. FEBS Letters, 579(20), 4423-4429. https://doi.org/10.1016/ j.febslet.2005.07.007

Kim, H. S., Lee, C. G. \& Lee, E. Y. (2011). Alginate lyase: structure, property and application. Biotechnology and Bioprocess Engineering, 16, 853-851.

Kumar, S., Narwak, S., Kumar, V., \& Prakash, O. (2010). $\alpha-$ glukosidase inhibitors from plants: a natural approach to treat diabetes. Pharmacognosy Reviews, 5(9), 19-29.

Li, L., Jiang, X., Guan, H., Wang, P., \& Guo, H. (2011). Three alginate lyases from marine bacterium Pseudomonas flourescens HZJ216: purification and characterization. Applied Biochemistry and Biotechnology, 164(3), 305-317.

Li, M., Li, G., Shang, Q., Chen, X., Liu, W., Pi, X., ... Wang, $X$. (2016). In vitro fermentation of alginate and its derivatives by human gut microbiota. Anaerobe, 39, $19-25$. h t t p s://doi.org/10.1016/ j.anaerobe.2016.02.003

Liu, J., Yang, S., Li, X., Yan, Q., Reaney, M. J. T., \& Jiang, Z. (2019). Alginate Oligosaccharides: Production, Biological Activities, and Potential Applications. Comprehensive Reviews in Food Science and Food Safety.doi:10.1111/1541-4337.12494.

Maharani, A. A., Husni, A., \& Ekantari, N. (2017). Karakteristik natrium alginat rumput laut cokelat Sargassum fluitans dengan metode ekstraksi yang berbeda. Jurnal Pengolahan Hasil Perikanan, 20(3), 478-487.

Mao, S., Zhang, T., Sun, W., \& Ren, X. (2012). The depolymerization of sodium alginate by oxidative 
degradation. Pharmaceutical Development and Technology, 17(6), 763-769. doi:10.3109/ 10837450.2011 .583927$.

Mushollaeni, W., \& Rusdiana, E. (2011). Karakterisasi natrium alginat dari Sargassum sp. Turbinaria sp. dan Padina sp. Jurnal Teknologi dan Industri Pangan, 22(1), 26-32.

Perkumpulan Endokrinologi Indonesia (PERKENI). (2011) Konsensus pengelolaan dan pencegahan diabetes melitus tipe 2 di Indonesia. Jakarta, ID: Perkumpulan Endokrinologi Indonesia.

Ramnani, P., Chitarrari, R., Tuohy, K., Grant, J., Hotchkiss, S., Philp, K., ... Rowland, I. (2012). Invitro fermentation and prebiotic potential of novel low molecular weight polysaccharides derived from agar and alginate seaweeds. Anaerobe, 18(1), 1-6. https://doi.org/ 10.1016/j.anaerobe.2011.08.003

Sakugawa, K., Ikeda, A., Takemura, A., \& Ono, H. (2004). Simplified method for estimation of composition of alginates by FTIR. Journal Applied Polymer Science, 93,1372-1377.

Samudra, A. G., Sani, K. F., \& Husni, A. (2017). In vitro áglucosidase and in vivo of anti-hyperglycemia activity extract of alginate from the brown marine algae Sargassum hystrix. Journal of Pharmacy research. 11(8), 927-931.

Sancheti, S., Sancheti, S., \& Seo, S.Y. (2009). Chaenomeles Sinensis : a potent á and âglukosidase inhibitor. American Journal of Pharmacology and Toxicology, 4(1), 8-11.

Sen, M. (2011). Effects of molecular weight and ratio of guluronic acid to mannuronic acid on the antioxidant properties of sodium alginate fractions prepared by radiation-induced degradation. Applied Radiation and isotopes. 126-129.

Shan, X., Liu, X., Hao, J., Cai, C., Fan, F., Dun, Y., ... Yu, G. (2016). In vitro and in vivo hypoglycemic effects of brown algal fucoidans. International Journal of Biological Macromolecules, 82, 249-255. https:// doi.org/10.1016/j.ijbiomac.2015.11.036

Sinurat, E., \& Marliani, R. (2017). Karakteristik Na-alginat dari rumput laut cokelat Sargassum crossifolium dengan perbedaan alat penyaring. Jurnal Pengolahan Hasil Perikanan, 20(2), 351-361. DOl: 10.17844/jphpi.v20i2.18103

Subaryono, Peranginangin, R., \& Suhartono, M.T. (2013). Alginate lyases: sources, mechanism of activity and potencial application. Squalen Bulletin of Marine \& Fisheries Postharvest \& Biotecnology, 8(3), 105-116.

Subaryono, Peranginangin, R., Suhartono, M.T., \& Zakaria, F.R. (2017). Aktivitas imunomodulator oligosakarida alginat (OSA) yang dihasilkan dari alginat asal Sargassum crassifolium. Jurnal Pengolahan Hasil Perikanan Indonesia, 20(1), 63-73.

Subaryono. (2016). Produksi enzimatik oligosakarida alginat (OSA) dari rumput laut Sargassum crassifolium dan aktivitas imunomodulatornya. Disertasi. Institut Pertanian Bogor, Bogor.

Tiwari, B. K., Pandey, K. B., Abidi, A. B., \& Rizvi, S. I. (2013). Review article: Markers of oxidative stress during diabete mellitus. Journal of Biomarkers, 1-8.

Tundis, R., Loizzo, M.R., \& Menichini, F. (2010). Natural products as á-amylase and á-glucosidase inhibitors and their hypoglycaemic potential in the treatment of diabetes: an update. Mini-Reviews in Medicinal Chemistry. 10(4), 315-331.

Ueno, M., \& Oda, T. (2014). Biological activities of alginate. Advances in Food and Nutrition Research. 72, 95-112.

Yudiati, E., Pringgenies, D., Djunaedi, A., Arifin, Z., \& Sudaryono, A. (2018). Free radicals scavenging activities of low molecular weight sodium alginat (LMWSA) from Sargassum polycystum, produced by thermal treatment. Aquaculture Indonesiana. 19(1), 21-27.

Wang, P., Jiang, X., Jiang, Y., Hu, X., Mou, H., Li, M., \& Guan, H. (2007). In vitro antioxidative activities of three marine oligosaccharides. Natural Product Research. 21 (7), 646-654

Zhou, R., Shi, X., Gao, Y., Cai, N., Jiang, Z., \& Xu, X. (2015). Anti-inflammatory Activity of Guluronate Oligosaccharides Obtained by Oxidative Degradation from Alginate in Lipopolysaccharide-Activated Murine Macrophage RAW 264.7 Cells. Journal of Agriculture and Food Chemistry, 63, 160-168.

Zhou, X., Yu, G., Guan, H., Yue, N., Zhang, Z., \& Li, H. (2007). Preparation of low-molecular-weight polyguluronate sulfate and its anticoagulant and antiinflammatory activities. Carbohydrate Polymers, 69(2), 272-279.

Zhu, Y., Wu, L., Chen, Y., Ni, H., Xiao, A., \& Cai, H. (2016). Characterization of an extracellular biofunctional alginate lyase from marine Microbulbifer sp. ALW1 and antioxidant activity of enzymatic hydrolysates. Microbiological Research, 182, 49-58. doi:10.1016/ j.micres.2015.09.004. 